\title{
Structure of the core oligosaccharide of a rough-type lipopolysaccharide of Pseudomonas syringae pv. phaseolicola
}

\author{
Evelina L. Zdorovenko ${ }^{1,2}$, Evgeny Vinogradov1,*, Galina M. Zdorovenko ${ }^{3}$, Buko Lindner2, \\ Olga V. Bystrova ${ }^{1,2}$, Alexander S. Shashkov ${ }^{1}$, Klaus Rudolph ${ }^{4}$, Ulrich Zähringer ${ }^{2}$ and Yuriy A. Knirel ${ }^{1,2}$ \\ ${ }^{1}$ N. D. Zelinsky Institute of Organic Chemistry, Russian Academy of Sciences Moscow, Russia; ${ }^{2}$ Research Center Borstel, \\ Leibniz Center for Medicine and Biosciences, Borstel, Germany; ${ }^{3}$ D.K. Zabolotny Institute of Microbiology and Virology, \\ National Academy of Sciences of Ukraine, Kiev, Ukraine; ${ }^{4}$ Institute for Plant Pathology and Plant Defence, Georg August University, \\ Göttingen, Germany
}

The core structure of the lipopolysaccharide (LPS) isolated from a rough strain of the phytopathogenic bacterium Pseudomonas syringae pv. phaseolicola, GSPB 711, was investigated by sugar and methylation analyses, Fourier transform ion-cyclotron resonance ESI MS, and one- and two-dimensional ${ }^{1} \mathrm{H}-,{ }^{13} \mathrm{C}$ - and ${ }^{31} \mathrm{P}-\mathrm{NMR}$ spectroscopy. Strong alkaline deacylation of the LPS resulted in two core-lipid A backbone undecasaccharide pentakisphosphates in the ratio $\approx 2.5: 1$, which corresponded to outer core glycoforms 1 and 2 terminated with either L-rhamnose or 3-deoxy-D-manno-oct-2-ulosonic acid (Kdo), respectively. Mild acid degradation of the LPS gave the major glycoform 1 core octasaccharide and a minor truncated glycoform 2 core heptasaccharide, which resulted from the cleavage of the terminal Kdo residues. The inner core of $P$. syringae is distinguished by a high degree of phosphorylation of L-glycero-D-manno-heptose residues with phosphate, diphosphate and ethanolamine diphosphate groups. The glycoform 1 core is structurally similar but not identical to one of the core glycoforms of the human pathogenic bacterium Pseudomonas aeruginosa. The outer core composition and structure may be useful as a chemotaxonomic marker for the $P$. syringae group of bacteria, whereas a more conserved inner core structure appears to be representative for the whole genus Pseudomonas.

Keywords: core oligosaccharide; glycoform; lipopolysaccharide structure; phytopathogen; Pseudomonas syringae.
The bacteria Pseudomonas syringae cause serious diseases in most cultivated plants and are widespread in nature as epiphytes. More than 50 pathovars of $P$. syringae and related species have been described based on the distinctive pathogenicity of the strains to one or more host plants [1]. The $P$. syringae group is characterized by a high degree of heterogeneity also in respect to genomic features. Recently, type strains of various $P$. syringae pathovars have been delineated into nine genomospecies [2]. However, the taxonomic status of the pathovars and genomospecies remains uncertain.

The lipopolysaccharide (LPS) is the major component of the outer membrane of Gram-negative bacteria, which plays

Correspondence to E. L. Zdorovenko, N. D. Zelinsky Institute of Organic Chemistry, Leninsky Prospekt 47, 119991, Moscow,

GSP-1, Russia. Fax: + 7095 1355328, Tel.: + 70959383613 ,

E-mail: evelina@ioc.ac.ru

Abbreviations: Cm, carbamoyl; CSD, capillary skimmer dissociation; 6dHex, 6-deoxyhexose; Etn, ethanolamine; FT-ICR, Fourier transform ion-cyclotron resonance; Hep, L-glycero-D-manno-heptose; Hex, hexose; HexN, hexosamine; HPAEC, high-performance anionexchange chromatography; Kdo, 3-deoxy-D-manno-oct-2-ulosonic acid; LPS, lipopolysaccharide; OS, oligosaccharide.

* Present address: Institute for Biological Sciences, National Research Council, 100 Sussex Drive, Ottawa, ON, Canada K1A 0R6.

(Received 29 June 2004, revised 30 September 2004,

accepted 27 October 2004) an important role in interaction of bacteria with their hosts. LPS is composed of lipid A, a core oligosaccharide, and an O-polysaccharide (O-antigen) built up of oligosaccharide repeats. The structures of the O-polysaccharides of all known serologically distinguishable smooth strains of $P$. syringae have been determined [3-12]. Aiming at solving the problems of recognition, taxonomy and classification of $P$. syringae strains, we established, for the first time, the full structure of the core region of the LPS from a rough strain of P. syringae pv. phaseolicola GSPB 711. According to published composition [11,13-16] and serological $[17,18]$ data, this core structure is shared by most $P$. syringae strains tested.

\section{Materials and methods}

Bacterium, growth and isolation of the lipopolysaccharide

P. syringae pv. phaseolicola rough strain GSPB 711 was received from the Göttingen Collection of Plant Pathogenic Bacteria (Germany) were grown on Potato agar at $22{ }^{\circ} \mathrm{C}$ for $24 \mathrm{~h}$, washed with physiological saline, separated by centrifugation, washed with acetone and dried.

LPS was isolated from dry bacterial cells by the method of Galanos [19] and purified by ultracentrifugation $(105000 \mathrm{~g}, 4 \mathrm{~h})$. The supernatant was dialyzed against distilled water and lyophilized. 


\section{Alkaline degradation of the lipopolysaccharide}

The LPS (110 mg) was treated with anhydrous hydrazine (4 mL) for $1 \mathrm{~h}$ at $37{ }^{\circ} \mathrm{C}$, then $16 \mathrm{~h}$ at $20{ }^{\circ} \mathrm{C}$. Hydrazine was flushed out in a stream of air at $30-33^{\circ} \mathrm{C}$, the residue washed with cold acetone at $4{ }^{\circ} \mathrm{C}$, dried in vacuum, dissolved in $4 \mathrm{M}$ $\mathrm{NaOH}(8 \mathrm{~mL})$ supplemented with a small amount of $\mathrm{NaBH}_{4}$, and then heated at $100{ }^{\circ} \mathrm{C}$ for $4 \mathrm{~h}$. After cooling to $4{ }^{\circ} \mathrm{C}$, the solution was acidified to $\mathrm{pH} 5.5$ with concentrated $\mathrm{HCl}$, extracted twice with dichloromethane, and the aqueous solution desalted by gel-permeation chromatography on a column $(60 \times 2.5 \mathrm{~cm})$ of Sephadex G-50 (Amersham Biosciences, Uppsala, Sweden) in pyridinium acetate buffer $(4 \mathrm{~mL}$ pyridine and $10 \mathrm{~mL}$ HOAc in $1 \mathrm{~L}$ water, $\mathrm{pH} 4.5$ ) at $30 \mathrm{~mL} \cdot \mathrm{h}^{-1}$. Elution was monitored with a differential refractometer (Knauer, Berlin, Germany). The isolated oligosaccharide mixture $\left(\mathrm{OS}_{\mathrm{NaOH}}\right)(35 \mathrm{mg})$ was fractionated by high-performance anion-exchange chromatography (HPAEC) on a semipreparative CarboPac PA1 column $(250 \times 9 \mathrm{~mm}$; Dionex, Sunnyvale, CA, USA $)$ using a linear gradient of $0.02-0.6 \mathrm{~m} \mathrm{NaOAc}$ in $0.1 \mathrm{~m} \mathrm{NaOH}$ at a flow rate of $2 \mathrm{~mL} \cdot \mathrm{min}^{-1}$ for $100 \mathrm{~min}$ and $2-\mathrm{mL}$ fractions were collected and analyzed by HPAEC using pulsed amperometric detection (Dionex) on an analytical CarboPac PA1 column $(250 \times 4.6 \mathrm{~mm})$ using the same eluent at $1 \mathrm{~mL} \cdot \mathrm{min}^{-1}$ for $30 \mathrm{~min}$. Desalting on a column $(40 \times 2.6 \mathrm{~cm})$ of Sephadex G-50 afforded two major oligosaccharides, $\mathrm{OS}_{\mathrm{NaOH}^{-}} \mathrm{I}$ and $\mathrm{OS}_{\mathrm{NaOH}^{-}}$II (7.2 and $3.6 \mathrm{mg}$, respectively), having retention times 11.7 and $18.0 \mathrm{~min}$ in analytical HPAEC.

\section{Mild-acid degradation of the lipopolysaccharide}

The LPS was dissolved in aqueous $1 \%$ HOAc and heated for $1.5 \mathrm{~h}$ at $100{ }^{\circ} \mathrm{C}$. The precipitate was removed by centrifugation (12 $000 \mathrm{~g}, 20 \mathrm{~min})$, and the supernatant fractionated by gel-permeation chromatography on a column $(40 \times 2.6 \mathrm{~cm})$ of Sephadex G-50 as described above to give a mixture of phosphorylated oligosaccharides $\left(\mathrm{OS}_{\mathrm{HOAc}}\right)$.

\section{Chemical analysis}

For neutral sugar analysis, the oligosaccharides $(0.5 \mathrm{mg}$ each) were hydrolyzed with $2 \mathrm{M} \mathrm{CF}_{3} \mathrm{CO}_{2} \mathrm{H}\left(120^{\circ} \mathrm{C}, 2 \mathrm{~h}\right)$, monosaccharides were conventionally converted into the alditol acetates and analyzed by GLC on a Hewlett-Packard HP 5890 Series II chromatograph (Palo Alto, CA, USA) equipped with a 30-m fused-silica SPB-5 column (Supelco, Bellefoute, PA, USA) using a temperature gradient of $150{ }^{\circ} \mathrm{C}(3 \mathrm{~min}) \rightarrow 320{ }^{\circ} \mathrm{C}$ at $5{ }^{\circ} \mathrm{C} \cdot \mathrm{min}^{-1}$. After hydrolysis of the oligosaccharides $(40 \mu \mathrm{g}$ each) with $4 \mathrm{M} \mathrm{HCl}(80 \mu \mathrm{L}$, $100{ }^{\circ} \mathrm{C}, 16 \mathrm{~h}$ ), amino components were analyzed as phenylthiocarbamoyl derivatives by HPLC on a reversed-phase Pico-Tag column $(150 \times 3.9 \mathrm{~mm})$ using buffers for PicoTag amino acid analysis of protein hydrolysates (Waters, Milford, MA, USA) at $42{ }^{\circ} \mathrm{C}$ and a flow rate $1 \mathrm{~mL} \cdot \mathrm{min}^{-1}$ for $10 \mathrm{~min}$; monitoring was performed with a dual $\lambda$ absorbance detector (Waters) at $254 \mathrm{~nm}$.

\section{Methylation analysis}

$\mathrm{OS}_{\mathrm{NaOH}^{-}}$-I and $\mathrm{OS}_{\mathrm{NaOH}^{-}}$-II (1 mg each) were dephosphorylated with aqueous $48 \% \mathrm{HF}(25 \mu \mathrm{L})$ at $4{ }^{\circ} \mathrm{C}$ for $16 \mathrm{~h}$, the solution was diluted with water and lyophilized, the products were $\mathrm{N}$-acetylated with $\mathrm{Ac}_{2} \mathrm{O}(100 \mu \mathrm{L})$ in aqueous saturated $\mathrm{NaHCO}_{3}$ at $20{ }^{\circ} \mathrm{C}$ for $1 \mathrm{~h}$ at stirring, reduced with $\mathrm{NaBH}_{4}$ and desalted by gel-permeation chromatography on Sephadex G-15. Methylation was performed by the procedure of Ciucanu and Kerek [20] with $\mathrm{CH}_{3} \mathrm{I}(0.3 \mathrm{~mL})$ in dimethylsulfoxide $(0.5 \mathrm{~mL})$ in the presence of solid $\mathrm{NaOH}$ (stirring for $20 \mathrm{~min}$ before and $2 \mathrm{~h}$ after adding $\mathrm{CH}_{3} \mathrm{I}$ ), the reaction mixture was diluted with water, the methylated compounds were extracted with chloroform, hydrolyzed with $3 \mathrm{M} \mathrm{CF}_{3} \mathrm{CO}_{2} \mathrm{H}\left(100{ }^{\circ} \mathrm{C}, 2 \mathrm{~h}\right)$, reduced with $\mathrm{NaBD}_{4}$, acetylated and analyzed by GLC MS on a HP Ultra 1 column $(25 \mathrm{~m} \times 0.3 \mathrm{~mm})$ using a Varian Saturn 2000 instrument (Palo Alto, CA, USA) equipped with an iontrap MS detector.

\section{Electrospray ionization mass spectrometry (ESI MS)}

High-resolution electrospray ionization Fourier transform ion-cyclotron resonance mass spectrometry (ESI FT-ICR MS) was performed in the negative ion mode using an ApexII-instrument (Bruker Daltonics, Billerica, USA) equipped with a $7 \mathrm{~T}$ actively shielded magnet and an Apollo electrospray ion source. Mass spectra were acquired using standard experimental sequences as provided by the manufacturer. Samples were dissolved at a concentration of $\approx 10 \mathrm{ng} \cdot \mathrm{\mu L}^{-1}$ in a $50: 50: 0.001(\mathrm{v} / \mathrm{v} / \mathrm{v})$ 2-propanol, water, and triethylamine mixture and sprayed at a flow rate of $2 \mu \mathrm{L} \cdot \mathrm{min}^{-1}$. Capillary entrance voltage was set to $3.8 \mathrm{kV}$, and dry gas temperature to $150{ }^{\circ} \mathrm{C}$. Capillary skimmer dissociation (CSD) was induced by increasing the capillary exit voltage from -100 to $-350 \mathrm{~V}$.

\section{NMR spectroscopy}

NMR spectra were obtained on a Varian Inova 500, Bruker DRX-500 and DRX-600 spectrometers (Karlsruhe, Germany) in $99.96 \% \mathrm{D}_{2} \mathrm{O}$ at 25 or $50{ }^{\circ} \mathrm{C}$ and $\mathrm{pD} 3,6$ or 9 (uncorrected), respectively, using internal acetone $\left(\delta_{\mathrm{H}}\right.$ $\left.2.225, \delta_{\mathrm{C}} 31.45\right)$ or external aqueous $85 \% \mathrm{H}_{3} \mathrm{PO}_{4}\left(\delta_{\mathrm{P}} 0.0\right)$ as reference. Prior to the measurements, the samples were lyophilized twice from $\mathrm{D}_{2} \mathrm{O}$. Bruker software XwINNMR 2.6 was used to acquire and process the data. Mixing times of 120 and $100 \mathrm{~ms}$ were used in TOCSY and 250 and $225 \mathrm{~ms}$ in ROESY experiments at 500 and $600 \mathrm{MHz}$, respectively.

\section{Results and Discussion}

Oligosaccharides derived by strong alkaline degaradation of the LPS [21] were used to determine the structure of the core-lipid A carbohydrate backbone of the $P$. syringae LPS. The LPS was O-deacetylated by mild hydrazinolysis and then N-deacylated under strong alkaline conditions (4 M $\left.\mathrm{NaOH}, 100{ }^{\circ} \mathrm{C}, 4 \mathrm{~h}\right)$. After desalting, the resultant mixture of oligosaccharides $\left(\mathrm{OS}_{\mathrm{NaOH}}\right)$ was fractionated by HPAEC on CarboPak PA1 at super-high $\mathrm{pH}$ to give the major and minor products $\left(\mathrm{OS}_{\mathrm{NaOH}}-\mathrm{I}\right.$ and $\mathrm{OS}_{\mathrm{NaOH}^{-}}-\mathrm{II}$, respectively).

The charge deconvoluted ESI FT-ICR mass spectrum of $\mathrm{OS}_{\mathrm{NaOH}}$ showed an abundant molecular ion with the molecular mass $2356.55 \mathrm{Da}$ as well as less intense peaks (Fig. 1). The measured molecular masses of two ions, 2356.55 and $2430.57 \mathrm{Da}$, were in agreement with those 


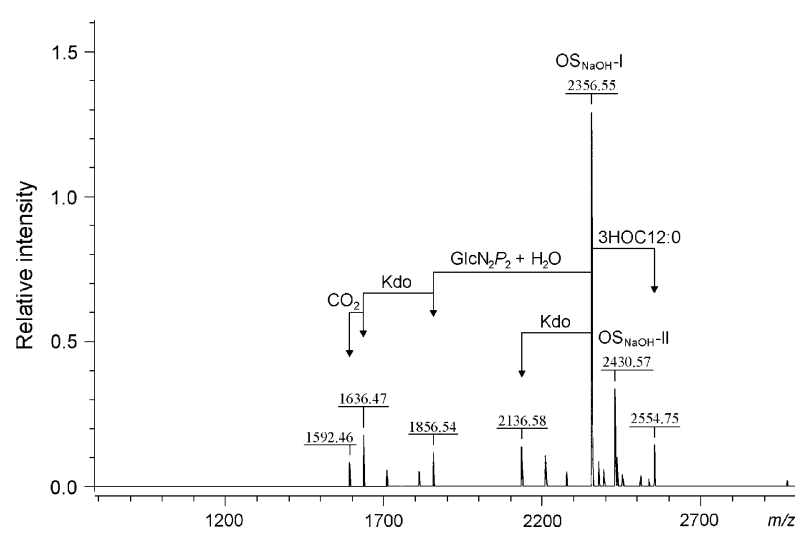

Fig. 1. Charge deconvoluted negative ion ESI FT-ICR mass spectrum of $\mathrm{OS}_{\mathrm{NaOH}}$ obtained by strong alkaline degradation of the LPS. 3HOC12:0 stands for the 3-hydroxydodecanoyl group.

calculated for undecasaccharide pentakisphosphates having the following composition: $6 \mathrm{dHex}_{1} \mathrm{Hex}_{2} \mathrm{Hep}_{2} \mathrm{Kdo}_{2} \mathrm{HexN}_{4} P_{5}$ and $\mathrm{Hex}_{2} \mathrm{Hep}_{2} \mathrm{Kdo}_{3} \mathrm{HexN}_{4} P_{5}\left(\mathrm{OS}_{\mathrm{NaOH}^{-}} \mathrm{I}\right.$ and $\mathrm{OS}_{\mathrm{NaOH}^{-}}-\mathrm{II}$, respectively), where $6 \mathrm{dHex}$ stands for a 6-deoxyhexose, Hex for a hexose, Hep for a heptose, HexN for a hexosamine, and Kdo for 3-deoxy-D-manno-oct-2-ulosonic acid. These compounds differ in one of the constituent monosaccharides, which is either a $6 \mathrm{dHex}$ residue or the third Kdo residue. Accordingly, the ${ }^{1} \mathrm{H}-\mathrm{NMR}$ spectra of $\mathrm{OS}_{\mathrm{NaOH}^{-}}{ }^{-\mathrm{I}}$ and $\mathrm{OS}_{\mathrm{NaOH}}$-II isolated by HPAEC showed signals for two and three Kdo residues, respectively. This finding is in agreement with a significantly higher retention time of $\mathrm{OS}_{\mathrm{NaOH}^{-}}-\mathrm{II}$ in HPAEC as compared with $\mathrm{OS}_{\mathrm{NaOH}^{-}} \mathrm{I}$ due to the presence of an additional negatively charged Kdo residue.

As depicted in Fig. 1, the other minor mass peaks belonged to (a) $\mathrm{OS}_{\mathrm{NaOH}^{-}} \mathrm{I}$ bearing a 3-hydroxydodecanoyl group $(\Delta m / z$ 198), which resulted from incomplete $\mathrm{N}$-deacylation of lipid A, and (b) to fragment ions due to losses of Kdo $(\Delta m / z-220)$, bisphosphorylated diglucosamine lipid A backbone $(\Delta m / z-500)$, and decarboxylation $(\Delta m / z-44)$.

The ${ }^{1} \mathrm{H}$ - and ${ }^{13} \mathrm{C}-\mathrm{NMR}$ spectra of $\mathrm{OS}_{\mathrm{NaOH}}-\mathrm{I}$ and $\mathrm{OS}_{\mathrm{NaOH}^{-}}$ II at two different temperature and $\mathrm{pD}$ conditions were assigned using two-dimensional COSY, TOCSY and ${ }^{1} \mathrm{H},{ }^{13} \mathrm{C}$ HSQC experiments (Table 1). Spin systems for all constituent monosaccharides, including rhamnose (Rha), Glc, L-glycero-D-manno-heptose (Hep), GlcN, GalN and Kdo, were identified by ${ }^{3} J$ coupling constants and using published data for structurally similar oligosaccharides derived from the Pseudomonas aeruginosa LPS [22,23]. The configurations of the glycosidic linkages were determined based on $J_{1,2}$ coupling constant values for Glc, GlcN and GalN (3-3.5 and $7-8 \mathrm{~Hz}$ for $\alpha$ - and $\beta$-linked monosaccharides, respectively) and by typical ${ }^{1} \mathrm{H}$ - and ${ }^{13} \mathrm{C}-\mathrm{NMR}$ chemical shifts for Rha, Hep and Kdo [24]. The anomeric configurations of Rha and Hep were confirmed by the presence of $\mathrm{H}-1, \mathrm{H}-2$ and no $\mathrm{H}-1, \mathrm{H}-3$ or $\mathrm{H}-1, \mathrm{H}-5$ cross-peaks in the two-dimensional ROESY spectra of the oligosaccharides.

Linkage and sequence analysis of $\mathrm{OS}_{\mathrm{NaOH}^{-}} \mathrm{I}$ and $\mathrm{OS}_{\mathrm{NaOH}}$-II was performed using a two-dimensional ROESY experiment. This revealed a lipid A carbohydrate backbone of a GlcN ${ }^{\mathrm{II}} \rightarrow \mathrm{GlcN}^{\mathrm{I}}$ disaccharide and an inner core region composed of two Hep and two Kdo residues (Hep ${ }^{\mathrm{I}}, \mathrm{Hep}^{\mathrm{II}}$, Kdo ${ }^{\mathrm{I}}$ and $\mathrm{Kdo}^{\mathrm{II}}$ ). The ROESY correlation pattern was essentially identical to that reported earlier for the inner core of the other Pseudomonas LPS studied $[22,23,25]$. In particular, a correlation of $\mathrm{Kdo}^{\mathrm{II}} \mathrm{H6}$ with $\mathrm{Kdo}^{\mathrm{I}} \mathrm{H} 3$ eq at $\delta 3.98 / 2.26$ showed the presence of an $\alpha 2 \rightarrow 4-$ linkage between these residues, and a correlation of $\mathrm{Hep}^{\mathrm{I}}$ $\mathrm{H} 1$ with $\mathrm{Kdo}^{\mathrm{I}} \mathrm{H} 5$ and $\mathrm{H} 7$ at $\delta 5.39 / 4.27$ and 5.39/3.87, respectively, is characteristic for an $\alpha 1 \rightarrow 5$-linkage [25].

The following correlations in the ROESY spectrum of $\mathrm{OS}_{\mathrm{NaOH}}-\mathrm{I}$ were observed between the anomeric protons of the outer core monosaccharides and the protons at the linkage carbons of the neighboring monosaccharide residues: GalN H1/Hep ${ }^{\mathrm{I}} \mathrm{H} 3$ at $\delta$ 5.50/4.09; $\mathrm{Glc}^{\mathrm{I}} \mathrm{H} 1 / \mathrm{GalN} \mathrm{H} 3$ at $\delta$ 4.69/4.25; $\mathrm{Glc}^{\mathrm{II}} \mathrm{H} 1 / \mathrm{GalN} \mathrm{H} 4$ at $\delta$ 4.97/4.35; $\mathrm{GlcN}^{\mathrm{III}}$ $\mathrm{H} 1 / \mathrm{Glc}^{\mathrm{I}} \mathrm{H} 2$ at $\delta$ 4.57/3.31; Rha $\mathrm{H} 1 / \mathrm{Glc}^{\mathrm{II}} \mathrm{H} 6 \mathrm{a}, 6 \mathrm{~b}$ at $\delta$ 4.77/ 3.79 and $4.77 / 3.91$. These data were in agreement with methylation analysis data (see below) and ${ }^{13} \mathrm{C}$-NMR chemical shift data showing downfield displacements of the signals for the corresponding linkage carbons (Table 2) as compared with their positions in the nonsubstituted monosaccharides [26].

In the ${ }^{31} \mathrm{P}-\mathrm{NMR}$ spectrum of $\mathrm{OS}_{\mathrm{NaOH}^{-}}$, five signals for phosphate groups were present at $\delta 2.58,2.72,4.29,4.47$ and 4.95 (at pD 6). A two-dimensional ${ }^{1} \mathrm{H},{ }^{31} \mathrm{P}-\mathrm{HMQC}$ experiment with $\mathrm{OS}_{\mathrm{NaOH}^{-I}}$ revealed a pattern essentially identical to that of Pseudomonas aeruginosa core-lipid A backbone oligosaccharide pentakisphosphate $[22,23]$ and defined the positions of the phosphate groups at $\mathrm{GlcN}^{\mathrm{I}} \mathrm{O} 1, \mathrm{GlcN}^{\mathrm{II}} \mathrm{O} 4$, $\mathrm{Hep}^{\mathrm{I}} \mathrm{O} 2$ and $\mathrm{O} 4$ and Hep ${ }^{\mathrm{II}}$ O6. These data together demonstrated that $\mathrm{OS}_{\mathrm{NaOH}}-\mathrm{I}$ has the structure shown in Fig. 2.

Similar studies, including ROESY and ${ }^{1} \mathrm{H},{ }^{31} \mathrm{P}-\mathrm{HMQC}$ experiments, demonstrated that $\mathrm{OS}_{\mathrm{NaOH}^{-}}$-II has the same structure except for that the terminal Rha residue in the outer core region is replaced with a terminal Kdo residue $\left(\mathrm{Kdo}^{\mathrm{III}}\right)$. The chemical shift for $\mathrm{H} 3 \mathrm{eq}$ in $\mathrm{Kdo}^{\mathrm{III}}$ was similar to that in $\alpha-\mathrm{Kdo}^{\mathrm{II}}$ and published values for $\alpha$-linked Kdo [27] ( $\delta 2.17$ vs. $2.06-2.13$ ) and significantly different from published data for $\beta$-linked Kdo [27] ( $\delta$ 2.37-2.47), thus indicating the $\alpha$-configuration of Kdo ${ }^{I I I}$.

An additional ${ }^{1} \mathrm{H},{ }^{13} \mathrm{C}$-HMBC experiment confirmed the linkage pattern and the sugar sequence in $\mathrm{OS}_{\mathrm{NaOH}^{-}}$-II but failed to reveal correlation for $\mathrm{Kdo}{ }^{\mathrm{III}} \mathrm{C} 2$ to a proton at the linkage carbon of the neighbouring sugar. Substitution with a keto sugar is known to cause a small downfield displacement of the linkage carbon signal ( $\alpha$-effect of glycosylation), and no displacement was observed in the ${ }^{13} \mathrm{C}$-NMR spectrum of $\mathrm{OS}_{\mathrm{NaOH}^{-}} \mathrm{II}$ for the $\mathrm{C} 6$ signal of $\mathrm{Glc}^{\mathrm{II}}$, which is a putative linkage carbon for Kdo ${ }^{\text {III }}$ (Table 2). However, the attachment of $\mathrm{Kdo}^{\mathrm{III}}$ at position 6 of $\mathrm{Glc}^{\mathrm{II}}$ could be demonstrated by a significant upfield $\beta$-effect of glycosylation on the $\mathrm{C} 5$ signal from $\delta 73.2$ in nonsubstituted

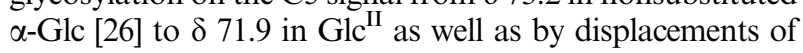
the H4-H6 signals from $\delta 3.42,3.84,3.84$, respectively, in nonsubstuted Glc [28] to $\delta 3.66,4.03,3.43$, respectively, in $\mathrm{Glc}^{\mathrm{II}}$ as a result of the anisotropy of the carboxyl carbon of $\mathrm{Kdo}^{\mathrm{III}}$. The data obtained suggested that $\mathrm{OS}_{\mathrm{NaOH}^{-}} \mathrm{II}$ has the structure shown in Fig. 2.

The structures of the alkaline degradation products were further confirmed by methylation analysis after dephosphorylaton, N-acetylation and borohydride reduction. The 
Table 1. 500-Mz ${ }^{1} \mathrm{H}-\mathrm{NMR}$ chemical shifts at $\mathrm{pD} 6$ at $25^{\circ} \mathrm{C}(\delta)$.

\begin{tabular}{|c|c|c|c|c|c|c|c|c|}
\hline \multirow[b]{3}{*}{ Compound } & \multicolumn{8}{|l|}{ Unit } \\
\hline & $\mathrm{H} 1$ & $\mathrm{H} 2$ & H3 & $\mathrm{H} 4$ & H5 & H6a & $\mathrm{H} 6 \mathrm{~b}$ & (7a) $\mathrm{H} 7 \mathrm{~b}$ \\
\hline & $\mathrm{H} 3 \mathrm{ax}$ & H3eq & $\mathrm{H} 4$ & H5 & H6 & $\mathrm{H} 7$ & H8a & $\mathrm{H} 8 \mathrm{~b}$ \\
\hline $\mathrm{OS}_{\mathrm{NaOH}^{-}}{ }^{-\mathrm{I}}$ & 5.48 & 2.99 & 3.72 & 3.47 & 4.09 & 3.74 & 4.28 & \\
\hline$\rightarrow-6)-\alpha-G_{c} N^{\mathrm{I}}-\left(1 \rightarrow P^{\mathrm{a}}\right.$ & 5.48 & 2.99 & 3.72 & 3.47 & 4.09 & 3.74 & 4.28 & \\
\hline$\rightarrow 6)-\alpha-\mathrm{GlcN}^{\mathrm{I}}-(1 \rightarrow P$ & 5.76 & 3.48 & 3.94 & 3.64 & 4.14 & 3.82 & 4.28 & \\
\hline$\rightarrow 6)-\beta-G_{c}{ }^{\mathrm{II}} 4 P-\left(1 \rightarrow^{\mathrm{a}}\right.$ & 4.59 & 2.82 & 3.65 & 3.65 & 3.65 & 3.42 & 3.67 & \\
\hline$\rightarrow 6)-\beta-\mathrm{GlcN}^{\mathrm{II}} 4 P-(1 \rightarrow$ & 4.87 & 3.16 & 3.91 & 3.87 & 3.78 & 3.53 & 3.77 & \\
\hline$\rightarrow 4,5)-\alpha-\mathrm{Kdo}^{\mathrm{I}}-\left(2 \rightarrow^{\mathrm{a}}\right.$ & 1.96 & 2.26 & 4.17 & 4.24 & 3.68 & 3.87 & 3.61 & 3.89 \\
\hline$\rightarrow 4,5)-\alpha-\mathrm{Kdo}^{\mathrm{I}}-(2 \rightarrow$ & 2.08 & 2.27 & 4.16 & 4.32 & 3.75 & 3.87 & 3.61 & 3.90 \\
\hline$\alpha-\mathrm{Kdo}^{\mathrm{II}}-\left(2 \rightarrow^{\mathrm{a}}\right.$ & 1.77 & 2.04 & 4.28 & 4.07 & 3.63 & 3.98 & 3.64 & 3.92 \\
\hline$\alpha-\mathrm{Kdo}^{\mathrm{II}}-(2 \rightarrow$ & 1.87 & 2.12 & 4.17 & 4.10 & 3.67 & 3.98 & 3.69 & 4.01 \\
\hline$\rightarrow 3)-\alpha-\operatorname{Hep}^{\mathrm{I}} 2 P 4 P-\left(1 \rightarrow^{\mathrm{a}}\right.$ & 5.39 & 4.38 & 4.09 & 4.33 & 4.32 & 4.15 & 3.81 & 4.00 \\
\hline$\rightarrow 3)-\alpha-$ Hep $^{\mathrm{I}} 2 P 4 P-(1 \rightarrow$ & 5.37 & 4.55 & 4.21 & 4.52 & 4.28 & 4.12 & 3.81 & 3.96 \\
\hline$\rightarrow 3)-\alpha-$ Hep $^{\mathrm{II}} 6 P-\left(1 \rightarrow^{\mathrm{a}}\right.$ & 5.21 & 4.32 & 4.15 & 4.21 & 3.94 & 4.39 & 3.71 & 3.71 \\
\hline$\rightarrow 3)-\alpha-$ Hep $^{\mathrm{II}} 6 P-(1 \rightarrow$ & 5.15 & 4.41 & 4.21 & 4.12 & 4.05 & 4.55 & 3.75 & 3.81 \\
\hline$\rightarrow 3,4)-\alpha-$ GalN- $\left(1 \rightarrow^{\mathrm{a}}\right.$ & 5.50 & 3.62 & 4.25 & 4.35 & 4.23 & 3.79 & 3.86 & \\
\hline$\rightarrow 3,4)-\alpha-$-GalN- $(1 \rightarrow$ & 5.60 & 3.87 & 4.43 & 4.47 & 4.25 & 3.83 & 3.91 & \\
\hline$\rightarrow 2)-\beta-G c^{\mathrm{I}}-\left(1 \rightarrow^{\mathrm{a}}\right.$ & 4.69 & 3.31 & 3.74 & 3.35 & 3.48 & 3.69 & 3.92 & \\
\hline$\rightarrow 2)-\beta-G_{c}{ }^{\mathrm{I}}-(1 \rightarrow$ & 4.75 & 3.37 & 3.76 & 3.40 & 3.49 & 3.73 & 3.96 & \\
\hline$\rightarrow 6)-\alpha-\mathrm{Glc}^{\mathrm{II}}-\left(1 \rightarrow^{\mathrm{a}}\right.$ & 4.97 & 3.49 & 3.73 & 3.61 & 4.24 & 3.79 & 3.91 & \\
\hline$\rightarrow 6)-\alpha-\mathrm{Glc}^{\mathrm{II}}-(1 \rightarrow$ & 5.03 & 3.54 & 3.75 & 3.67 & 4.22 & 3.81 & 3.95 & \\
\hline$\beta-G_{c} N^{I I I}-\left(1 \rightarrow^{\mathrm{a}}\right.$ & 4.57 & 2.77 & 3.36 & 3.49 & 3.42 & 3.82 & 3.88 & \\
\hline$\beta-\mathrm{GlcN}^{\mathrm{III}}-(1 \rightarrow$ & 4.96 & 3.26 & 3.72 & 3.60 & 3.57 & 3.89 & 3.92 & \\
\hline$\alpha$-L-Rha- $\left(1 \rightarrow^{\mathrm{a}}\right.$ & 4.77 & 3.99 & 3.78 & 3.42 & 3.73 & 1.28 & & \\
\hline$\alpha$-L-Rha- $(1 \rightarrow$ & 4.80 & 4.02 & 3.82 & 3.44 & 3.76 & 1.32 & & \\
\hline $\mathrm{OS}_{\mathrm{NaOH}}-\mathrm{II}$ & 5.77 & 3.50 & 3.94 & 3.65 & 4.14 & 3.83 & 4.31 & \\
\hline$\rightarrow-6)-\alpha-\mathrm{GlcN}^{\mathrm{I}}-(1 \rightarrow P$ & 5.77 & 3.50 & 3.94 & 3.65 & 4.14 & 3.83 & 4.31 & \\
\hline$\rightarrow 6)-\beta-G_{l c N}{ }^{I I} 4 P-(1 \rightarrow$ & 4.86 & 3.16 & 3.91 & 3.87 & 3.78 & 3.51 & 3.76 & \\
\hline$\rightarrow 4,5)-\alpha-\mathrm{Kdo}^{\mathrm{I}}-(2 \rightarrow$ & 2.07 & 2.28 & 4.15 & 4.32 & 3.74 & 3.88 & 3.61 & 3.92 \\
\hline$\alpha-\mathrm{Kdo}^{\mathrm{II}}-(2 \rightarrow$ & 1.86 & 2.12 & 4.18 & 4.10 & 3.68 & 4.03 & 3.70 & 4.00 \\
\hline$\rightarrow 3)-\alpha-$ Hep $^{\mathrm{I}} 2 P 4 P-(1 \rightarrow$ & 5.39 & 4.56 & 4.21 & 4.53 & 4.33 & 4.13 & 3.83 & 4.00 \\
\hline$\rightarrow 3)-\alpha-$ Hep $^{\mathrm{II}} 6 P-(1 \rightarrow$ & 5.15 & 4.41 & 4.22 & 4.12 & 4.05 & 4.56 & 3.76 & 3.83 \\
\hline$\rightarrow 3,4)-\alpha-$ GalN- $(1 \rightarrow$ & 5.60 & 3.79 & 4.36 & 4.47 & 4.24 & 3.90 & 3.93 & \\
\hline$\rightarrow 2)-\beta-G c^{\mathrm{I}}-(1 \rightarrow$ & 4.71 & 3.57 & 3.66 & 3.53 & 3.46 & 3.78 & 3.94 & \\
\hline$\rightarrow 6)-\alpha-\mathrm{Glc}^{\mathrm{II}}-(1 \rightarrow$ & 5.06 & 3.54 & 3.73 & 3.66 & 4.03 & 3.43 & 3.75 & \\
\hline$\beta-G_{l c N}{ }^{I I I}-(1 \rightarrow$ & 5.01 & 3.25 & 3.79 & 3.56 & 3.52 & 3.86 & 3.86 & \\
\hline$\alpha-\mathrm{Kdo}^{\mathrm{III}}-(1 \rightarrow$ & 1.82 & 2.17 & 4.12 & 4.06 & 3.62 & 3.96 & 3.64 & 3.94 \\
\hline
\end{tabular}

${ }^{\text {a }}$ Data at $\mathrm{pD} 9$ at $50{ }^{\circ} \mathrm{C}$.

analysis of $\mathrm{OS}_{\mathrm{NaOH}}$-I revealed terminal Rha, 2-substituted and 6-substituted Glc, 3-substituted Hep, 6-substituted 2-acetamido-2-deoxyglucitol (GlcNAc-ol; from GlcN-P of lipid A), terminal GlcNAc and 3,4-disubstituted GalNAc in the ratios $0.67: 1: 1.67: 0.5: 0.83: 0.75: 0.17$ (detector response), respectively, as well as a trace amount of terminal Glc. No 6-substituted GlcNAc, expected from GlcN4P of lipid A was observed, most likely, owing to cleavage of the Kdo residue attached to GlcN4P at position 6 in the course of dephosphorylaton of $\mathrm{OS}_{\mathrm{NaOH}^{-}} \mathrm{I}$ under acidic conditions that converted the 6-substituted residue into a terminal residue. A similar analysis of $\mathrm{OS}_{\mathrm{NaOH}^{-}}$II resulted in identification of terminal, 2-substituted and 6-substituted Glc, 3-substituted Hep, 6-substituted GlcNAc-ol, terminal GlcNAc and 3,4-disubstituted GalNAc in the ratios $1.25: 1: 1.25: 0.38: 1.13: 0.63: 0.13$, respectively, as well as a trace amount of terminal Rha. These data could be accounted for by the attachment of $\mathrm{Kdo}^{\mathrm{III}}$ in $\mathrm{OS}_{\mathrm{NaOH}^{-}}$II to the same position 6 of one of the Glc residues as Rha in $\mathrm{OS}_{\mathrm{NaOH}}-\mathrm{I}$, whereas terminal Glc resulted from partial removal of $\mathrm{Kdo}^{\mathrm{III}}$ from 6-substituted Glc during dephosphorylation of $\mathrm{OS}_{\mathrm{NaOH}}$-II.

For analysis of alkali-labile groups, the LPS was subjected to mild-acid hydrolysis and an oligosaccharide mixture $\left(\mathrm{OS}_{\mathrm{HOAc}}\right)$ was isolated by gel-permeation chromatography on Sephadex G-50. Sugar analysis of $\mathrm{OS}_{\mathrm{HOAc}}$ by GLC of the acetylated alditols revealed Rha, Glc, Hep, GlcN and GalN in the ratios $1: 2.5: 0.7: 0.5: 0.1$ (detector response), respectively, and analysis using an amino acid analyser showed the presence of alanine and ethanolamine.

Charge deconvoluted negative ion ESI FT-ICR massspectrum of $\mathrm{OS}_{\mathrm{HOAc}}$ (not shown) displayed a number of molecular ions, the most abundant from which had the molecular masses 1810.53 and $1933.52 \mathrm{Da}$ and could be assigned to a $\mathrm{Rha}_{1} \mathrm{Glc}_{2} \mathrm{Hep}_{2} \mathrm{Kdo}_{1} \mathrm{HexN}_{2} P_{3} \mathrm{Ac}_{1} \mathrm{Ala}_{1} \mathrm{Cm}_{1}$ octasaccharide trisphosphate $\left(\mathrm{OS}_{\mathrm{HOAc}}-\mathrm{I}\right)$ and that contain- 
Table 2. 125-MHz ${ }^{13} \mathrm{C}-\mathrm{NMR}$ chemical shifts at $\mathrm{pD} 6$ at $25^{\circ} \mathrm{C}(\delta)$.

\begin{tabular}{|c|c|c|c|c|c|c|c|c|}
\hline \multirow[b]{2}{*}{ Compound } & \multicolumn{8}{|l|}{ Unit } \\
\hline & $\mathrm{C} 1$ & $\mathrm{C} 2$ & $\mathrm{C} 3$ & $\mathrm{C} 4$ & $\mathrm{C} 5$ & C6 & $\mathrm{C} 7$ & $\mathrm{C} 8$ \\
\hline \multicolumn{9}{|l|}{$\mathrm{OS}_{\mathrm{NaOH}^{-}}{ }^{-\mathrm{I}}$} \\
\hline$\rightarrow-6)-\alpha-\mathrm{GlcN}^{\mathrm{I}} 1 P$ & 93.9 & 56.1 & 72.9 & 71.0 & 73.0 & 70.7 & & \\
\hline$\rightarrow 6)-\beta-\mathrm{GlcN}^{\mathrm{II}} 4 P-(1 \rightarrow$ & 102.4 & 57.0 & 74.3 & 75.4 & 75.4 & 63.9 & & \\
\hline$\rightarrow 4,5)-\alpha-\mathrm{Kdo}^{\mathrm{I}}-(2 \rightarrow$ & & 100.7 & 35.5 & 72.3 & 68.9 & 73.4 & 70.1 & 65.0 \\
\hline$\alpha-\mathrm{Kdo}^{\mathrm{II}}-(2 \rightarrow$ & & 102.8 & 36.3 & 66.6 & 67.9 & 73.3 & 72.0 & 64.0 \\
\hline$\rightarrow 3)-\alpha-\mathrm{Hep}^{\mathrm{I}} 2 P 4 P-(1 \rightarrow$ & 98.6 & 74.8 & 75.5 & 70.1 & 73.7 & 69.9 & 64.2 & \\
\hline$\rightarrow 3)-\alpha-\mathrm{Hep}^{\mathrm{II}} 6 P-(1 \rightarrow$ & 103.3 & 70.1 & 78.0 & 66.6 & 73.0 & 73.3 & 63.0 & \\
\hline$\rightarrow 3,4)-\alpha$-GalN- $(1 \rightarrow$ & 97.6 & 51.5 & 79.5 & 76.6 & 73.4 & 60.7 & & \\
\hline$\rightarrow 2)-\beta-G^{\prime}{ }^{I}-(1 \rightarrow$ & 104.6 & 84.1 & 76.7 & 71.1 & 76.5 & 61.9 & & \\
\hline$\rightarrow 6)-\alpha-\mathrm{Glc}^{\mathrm{II}}-(1 \rightarrow$ & 100.2 & 72.9 & 73.8 & 69.8 & 71.4 & 67.3 & & \\
\hline$\beta-G^{\prime c N}{ }^{I I I}-(1 \rightarrow$ & 106.0 & 58.3 & 76.7 & 70.3 & 77.0 & 61.5 & & \\
\hline$\alpha$-L-Rha- $(1 \rightarrow$ & 102.1 & 71.0 & 71.2 & 73.1 & 69.6 & 18.0 & & \\
\hline \multicolumn{9}{|l|}{$\mathrm{OS}_{\mathrm{NaOH}}-\mathrm{II}$} \\
\hline$\rightarrow-6)-\alpha-\mathrm{GlcN}^{\mathrm{I}} 1 P$ & 93.4 & 55.8 & 70.9 & 71.2 & 72.3 & 71.1 & & \\
\hline$\rightarrow 6)-\beta-\mathrm{GlcN}^{\mathrm{II}} 4 P-(1 \rightarrow$ & 100.7 & 57.3 & 73.3 & 76.1 & 75.5 & 64.2 & & \\
\hline$\rightarrow 4,5)-\alpha-\mathrm{Kdo}^{\mathrm{I}}-(2 \rightarrow$ & & & 35.9 & 72.8 & 69.7 & 73.9 & 70.7 & 65.4 \\
\hline$\alpha-\mathrm{Kdo}^{\mathrm{II}}-(2 \rightarrow$ & & & 36.6 & 67.3 & 68.2 & 74.2 & 72.3 & 64.8 \\
\hline$\rightarrow 3)-\alpha-\mathrm{Hep}^{\mathrm{I}} 2 P 4 P-(1 \rightarrow$ & 98.9 & 76.1 & 75.7 & 72.2 & 73.7 & 70.8 & 64.8 & \\
\hline$\rightarrow 3)-\alpha-\mathrm{Hep}^{\mathrm{II}} 6 P-(1 \rightarrow$ & 103.8 & 70.9 & 79.8 & 67.1 & 73.3 & 74.9 & 63.1 & \\
\hline$\rightarrow 3,4)-\alpha$-GalN-( $1 \rightarrow$ & a & 52.4 & 79.0 & 80.8 & 73.4 & 61.9 & & \\
\hline$\rightarrow 2)-\beta-\mathrm{Glc}^{\mathrm{I}}-(1 \rightarrow$ & 104.8 & 85.5 & 77.4 & 71.4 & 77.7 & 62.8 & & \\
\hline$\rightarrow 6)-\alpha-\mathrm{Glc}^{\mathrm{II}}-(1 \rightarrow$ & 102.7 & 73.5 & 74.9 & 70.4 & 71.9 & 61.9 & & \\
\hline$\beta-G^{-1 c N}{ }^{\mathrm{III}}-(1 \rightarrow$ & 106.0 & 58.3 & 76.7 & 70.3 & 77.0 & 61.5 & & \\
\hline$\alpha-\mathrm{Kdo}^{\mathrm{III}}-(1 \rightarrow$ & & 101.1 & 35.8 & 67.8 & 67.7 & 73.1 & 71.1 & 65.1 \\
\hline
\end{tabular}

${ }^{\text {a }}$ No $\mathrm{H} 1, \mathrm{Cl}$ cross-peak was present in the ${ }^{1} \mathrm{H},{ }^{13} \mathrm{C}$ HSQC spectrum.

ing an additional ethanolamine phosphate group (Etn $P$ ) $\left(\mathrm{OS}_{\mathrm{HOAc}}-\mathrm{II}\right)$. Two other nonsugar groups present in $\mathrm{OS}_{\mathrm{HOAc}}$, viz. $\mathrm{N}$-alanyl and O-carbamoyl $(\mathrm{Cm})$ groups, are conserved components of the LPS core of pseudomonads [29-31]; Ala is typically linked to GalN, and the location of $\mathrm{Cm}$ at $\mathrm{Hep}^{\mathrm{II}} \mathrm{O} 7$ in the LPS of $P$. syringae has been demonstrated earlier [32].

Further mass peaks belonged to the oligosaccharides that contain one phosphate group more than $\mathrm{OS}_{\mathrm{HOAc}}-\mathrm{I}$ and $\mathrm{OS}_{\mathrm{HOAc}}$-II $(\Delta m / z$ 80) and, hence, include a diphosphate group. Another series of less intense mass peaks corresponded to Rha-lacking heptasaccharides with molecular masses 1664.43 and $1787.47 \mathrm{Da}\left(\mathrm{OS}_{\mathrm{HOAc}}-\mathrm{III}\right.$ and $\mathrm{OS}_{\mathrm{HOAc}}-\mathrm{IV}$, respectively). They were evidently derived from the corresponding octasacharides that initially contained $\mathrm{Kdo}^{\mathrm{III}}$, which was cleaved by mild-acid hydrolysis. Yet another minor series belonged to GlcNAc-lacking compounds $(\Delta m / z-203)$, and, finally, each ion was accompanied by an ion with $\mathrm{Kdo}^{\mathrm{I}}$ in an anhydro form $(\Delta m / z-18)$ [33].

The CSD negative ion ESI FT-ICR mass spectrum of $\mathrm{OS}_{\mathrm{HOAc}}$ (Fig. 3) showed a cleavage of the glycosidic linkage between Hep ${ }^{\mathrm{I}}$ and $\mathrm{Hep}^{\mathrm{II}}$ accompanied by a partial loss of the carbamoyl group $(\Delta m / z-43)$ [22-24]. The major Z-fragments from the reducing end with $m / z$ 571.10, 651.08 and 694.13 contained Hep ${ }^{\mathrm{I}}$ with two phosphate groups $\left(Z_{2 P}\right)$, one phosphate group and one diphosphate group $\left(Z_{3 P}\right)$, or one phosphate and one ethanolamine diphosphate group $\left(\mathrm{Z}_{3 P \text { Etn }}\right)$, respectively. The major $\mathrm{B}$ fragments from the nonreducing end of the octasaccharides with $m / z \quad 1219.49$ and $1299.48\left(\mathrm{~B}_{1 P}\right.$ and $\left.\mathrm{B}_{2 P}\right)$ and the
Rha-lacking heptasaccharides with $m / z 1073.41$ and 1153.40 had one phosphate or one diphosphate group on Hep ${ }^{\text {II }}$, respectively. Taking into account the location of two phosphorylation sites on Hep ${ }^{\mathrm{I}}$ and one phosphorylation site on Hep ${ }^{\mathrm{II}}$ (see structures of $\mathrm{OS}_{\mathrm{NaOH}^{-}}$I and $\mathrm{OS}_{\mathrm{NaOH}^{-}}-\mathrm{II}$ ), it could be inferred that $\mathrm{Etn} P$ is located on $\mathrm{Hep}^{\mathrm{I}}$, whereas diphosphate groups may occupy either of the Hep residues.

The ${ }^{13} \mathrm{C}$-NMR spectrum of $\mathrm{OS}_{\mathrm{HOAc}}$ (Fig. 4) contained signals for methyl groups of an N-acetyl group at $\delta$ 23.3, an alanyl group at $\delta 19.9$ and Rha (C6) at $\delta 17.9$, a methylene group of $\mathrm{Kdo}^{\mathrm{I}}$ (C3) at $\delta 34.0$ and ethanolamine $\left(\mathrm{CH}_{2} \mathrm{~N}\right)$ at $\delta 41.0$, three nitrogen-bearing carbons $(\mathrm{C} 2$ of Ala, GalN and GlcN) at $\delta 50.3,51.0$ and 56.8, carbonyl groups of the acyl groups and a carboxyl group $(\mathrm{C} 1)$ of $\mathrm{Kdo}^{\mathrm{I}}$ at $\delta 172-176$ and an O-carbamoyl group $\left(\mathrm{NH}_{2} \mathrm{CO}\right)$ at $\delta 159.4$ (compare $\delta 159.6$ for $\mathrm{Cm}$ in the core oligosaccharide of $P$. aeruginosa [34]).

The ${ }^{1} \mathrm{H}-\mathrm{NMR}$ spectrum of $\mathrm{OS}_{\mathrm{HOAc}}$ showed signals for methyl groups of an $\mathrm{N}$-acetyl group at $\delta 2.04$ (singlet) on GlcN, an N-alanyl group on GalN at $\delta 1.62$ (two overlapping doublets, $J_{2,3}-6 \mathrm{~Hz}$ ) and $\mathrm{H} 6$ of Rha at $\delta 1.31$ (doublet, $J_{5,6} 6.5 \mathrm{~Hz}$ ) as well as the $\mathrm{CH}_{2} \mathrm{~N}$ group of ethanolamine at $\delta 3.32$ (a broad signal) with the ratios of integral intensivities $\approx 1: 1: 0.7: 0.4$. These data were in agreement with the relative content of $\mathrm{OS}_{\mathrm{NaOH}^{-}} \mathrm{I}$ and $\mathrm{OS}_{\mathrm{NaOH}^{-}}$-II in the alkaline degradation products of the LPS and indicated that Rha is present in $\approx 70 \%$ and $\mathrm{Kdo}^{\mathrm{III}}$ in $\approx 30 \%$ of the initial LPS molecules. They also showed that the content of Etn $P$-containing molecules in $\mathrm{OS}_{\mathrm{HOAc}}$ is $\approx$ $60 \%$ but it cannot be excluded that the Etn $P$ content in the 


$$
\begin{aligned}
& \left.\left.\left.\left.\left.{ }^{P-6)}\right\rceil \quad P-2\right)\right\rceil \Gamma^{(4-P} \quad P-4\right)\right\rceil \\
& \beta-G_{c N}{ }^{\mathrm{III}}-(1 \rightarrow 2)-\beta-\mathrm{Glc}^{\mathrm{I}}-(1 \rightarrow 3)-\alpha-\mathrm{GalN}^{-}(1 \rightarrow 3)-\alpha-\mathrm{Hep}^{\mathrm{II}}-(1 \rightarrow 3)-\alpha-\mathrm{Hep}^{\mathrm{I}}-(1 \rightarrow 5)-\alpha-\mathrm{Kdo}^{\mathrm{I}}-(2 \rightarrow 6)-\beta-\mathrm{GlcN}^{\mathrm{II}}-(1 \rightarrow 6)-\alpha-\mathrm{GlcN}^{\mathrm{I}}-(1 \rightarrow P \\
& \left.\left.\alpha-L-R h a-(1 \rightarrow 6)-\alpha-\text { Glc }^{\text {II }}-(1 \rightarrow 4)\right\rfloor \quad \alpha-\text { Kdo }^{\text {II }}-(2 \rightarrow 4)\right\rfloor \\
& \mathrm{OS}_{\mathrm{NaOH}}-\mathrm{I}
\end{aligned}
$$

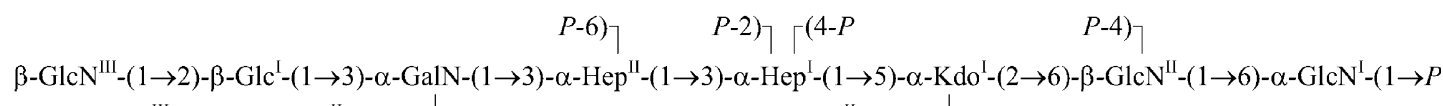

$$
\begin{aligned}
& \left.\left.\alpha-\mathrm{Kdo}^{\mathrm{III}}-(2 \rightarrow 6)-\alpha-\mathrm{Glc}^{\mathrm{II}}-(1 \rightarrow 4)\right\rfloor \quad \alpha-\mathrm{Kdo}^{\mathrm{II}}-(2 \rightarrow 4)\right\rfloor \\
& \mathrm{OS}_{\mathrm{NaOH}}-\mathrm{II}
\end{aligned}
$$

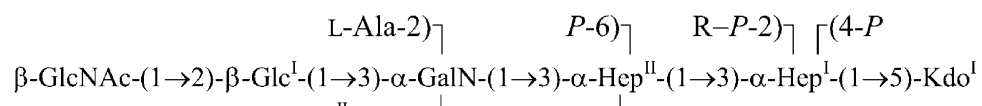

$$
\begin{aligned}
& \left.\left.\alpha-\mathrm{L}-\mathrm{Rha}-(1 \rightarrow 6)-\alpha-\mathrm{Glc}^{\mathrm{II}}-(1 \rightarrow 4)\right\rfloor \quad \mathrm{Cm}-7\right)^{\rfloor} \\
& \mathrm{OS}_{\mathrm{HOAc}}-\mathrm{I} \mathrm{R}=\mathrm{H}, \mathrm{OS}_{\mathrm{HOAc}}-\mathrm{II} \mathrm{R}=\mathrm{Etn} P
\end{aligned}
$$

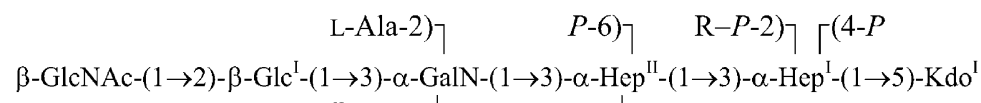

$$
\begin{aligned}
& \left.\left.\left.\alpha-\mathrm{Glc}^{\mathrm{II}}-(1 \rightarrow 4)\right\rfloor \quad \mathrm{Cm}-7\right)\right\rfloor \\
& \mathrm{OS}_{\mathrm{HOAc}}-\text { III } \mathrm{R}=\mathrm{H}, \mathrm{OS}_{\mathrm{HOAc}}-\mathrm{IV} \mathrm{R}=\mathrm{Etn} P
\end{aligned}
$$

Fig. 2. Structures of $\mathrm{OS}_{\mathrm{NaOH}}$ and $\mathrm{OS}_{\mathrm{HOAc}}$ obtained by strong alkaline degradation and mild-acid hydrolysis of the LPS, respectively. In some OS molecules position 4 of $\mathrm{Hep}^{\mathrm{I}}$ or position 6 of $\mathrm{Hep}^{\mathrm{II}}$ is occupied by a diphosphate group. All monosaccharides are in the pyranose form and have the D-configuration unless stated otherwise. Cm, carbamoyl; Etn, ethanolamine; Hep, L-glycero-D-manno-heptose; Kdo, 3-deoxy-D-manno-oct-2ulosonic acid; Rha, rhamnose.

intact LPS is higher because this group may be partially lost during mild-acid degradation of the LPS. The major signals for the methylene group $(\mathrm{H} 3)$ of $\mathrm{Kdo}^{\mathrm{I}}$ were observed at $\delta$ 1.94 and 2.25. The alanine signal was split owing to the presence of two types of molecules, one containing and the other lacking Rha. The ${ }^{31} \mathrm{P}-\mathrm{NMR}$ spectrum of $\mathrm{OS}_{\mathrm{HOAc}}$ showed signals for monophosphate and diphosphate groups at $\delta 1-3$ and -10 to -8 (at $\mathrm{pD} 3$ ), respectively.

The ${ }^{1} \mathrm{H}-\mathrm{NMR}$ spectrum of the $\mathrm{OS}_{\mathrm{HOAc}}$ was too complex to be fully assigned by two-dimensional NMR experiments owing to high degree of structural heterogeneity due to the occurrence of two outer core glycoforms, multiple forms of $\mathrm{Kdo}^{\mathrm{I}}$ and nonstoichiometric phosphorylation. However, the ${ }^{1} \mathrm{H},{ }^{31} \mathrm{P}$ HMQC and ${ }^{1} \mathrm{H},{ }^{31} \mathrm{P}$ HMQC-TOCSY spectra of $\mathrm{OS}_{\mathrm{HOAc}}$ showed essentially the same correlation pattern as the corresponding spectra of the core oligosaccharides obtained by mild-acid degradation of the $P$. aeruginosa LPS [35,36]. Particularly, the signals of the diphosphate diester group gave correlations to $\mathrm{CH}_{2} \mathrm{O}$ of ethanolamine and $\mathrm{H} 2$ of Hep ${ }^{1}$ at $\delta-9.9 / 4.26$ and $-9.6 / 4.63$ in the ${ }^{1} \mathrm{H}^{31} \mathrm{P}$ HMQC spectrum, and, in addition, to $\mathrm{CH}_{2} \mathrm{~N}$ of ethanolamine and $\mathrm{H} 1$ of $\mathrm{Hep}^{\mathrm{I}}$ at $\delta-9.9 / 3.32$ and $-9.6 / 5.37$ in the ${ }^{1} \mathrm{H},{ }^{31} \mathrm{P}$ HMQC-TOCSY spectrum, respectively. This finding showed that Etn $P P$ group in the LPS of $P$. syrinage is located at the same position as in the $P$. aeruginosa LPS, i.e. at Hep ${ }^{\mathrm{I}} \mathrm{O} 2$. The monophosphate groups showed crosspeaks, which could be assigned to correlations to $\mathrm{H} 4$ of $\mathrm{Hep}^{\mathrm{I}}$ and $\mathrm{H} 6$ and Hep ${ }^{\mathrm{II}}$, as well as to a minor part of $\mathrm{H} 2$ of Hep $^{I}$ because substitution with $\operatorname{Etn} P$ is incomplete. Signals for minor diphosphate monoester groups were too weak and gave no cross-peaks; their location at two other phosphorylation sites, i.e. Hep ${ }^{\mathrm{I}} \mathrm{O} 4$ and Hep ${ }^{\mathrm{II}}$ O6, could be inferred from the CSD MS data of $\mathrm{OS}_{\mathrm{HOAc}}$ (see above).

These data defined the structure of the $\mathrm{OS}_{\mathrm{HOAc}}$ (Fig. 2) as well as of the full core oligosaccharide of P. syringae pv. phaseolicola GSPB 711 (Fig. 5). The structure of the $P$. syringae LPS core is similar but not identical to that of other members of the genus Pseudomonas studied so far, including $P$. aeruginosa [22,30,35-39], P. fluorescens [25,29], $P$. stutzeri [40] and $P$. tolaasii [41]. In all these bacteria, the inner core region has the same carbohydrate backbone and may differ only in the presence and the content of diphosphate and ethanolamine diphosphate groups. Therefore, the structure of the inner core may serve as a chemotaxonomic marker for the genus Pseudomonas. On the other hand, the outer core region varies in composition and structure in different Pseudomonas species, that of $P$. syringae being distinguished by the simultaneous presence of GlcNAc and Rha. The same LPS core composition was revealed by other studies in all $P$. syringae strains tested [11,13-16], and, hence, it may be used as a chemotaxonomic marker for the $P$. syringae group of bacteria, which to date has an uncertain taxonomic status.

A peculiar structural feature of the P. syringae LPS studied in this work is the existence of two outer core glycoforms terminated with either Rha or Kdo. A similar alternation of terminal GlcNAc and Kdo residues on a Gal residue has been reported in the outer core region of Proteus 


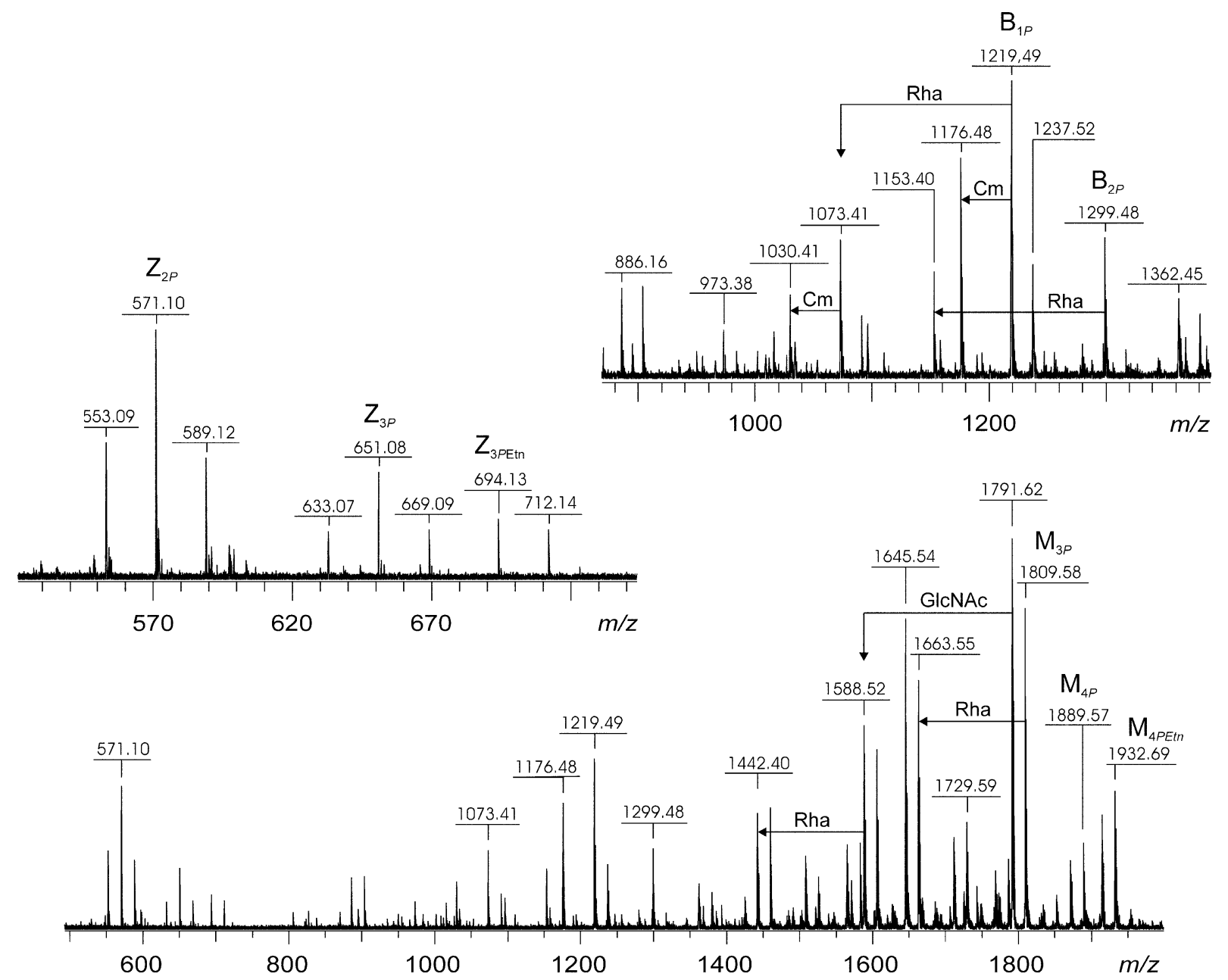

Fig. 3. Capillary skimmer dissociation negative ion ESI FT-ICR mass spectrum of $\mathrm{OS}_{\mathrm{HOAc}}$ obtained by mild-acid hydrolysis of the LPS and extensions of the regions of the $\mathbf{B}$ - and $\mathbf{Z}$-fragment ions due to the cleavage between the Hep residues. $\mathbf{M}_{2 P}, \mathbf{M}_{3 P}, \mathbf{M}_{4 P}$ refer to the molecular ions and $\mathrm{Z}_{1 P}, \mathrm{Z}_{2 P}$, $\mathrm{B}_{1 P}, \mathrm{~B}_{2 P}$ to the fragment ions with one to four phosphate groups. For abbreviations see legend to Fig. 2.

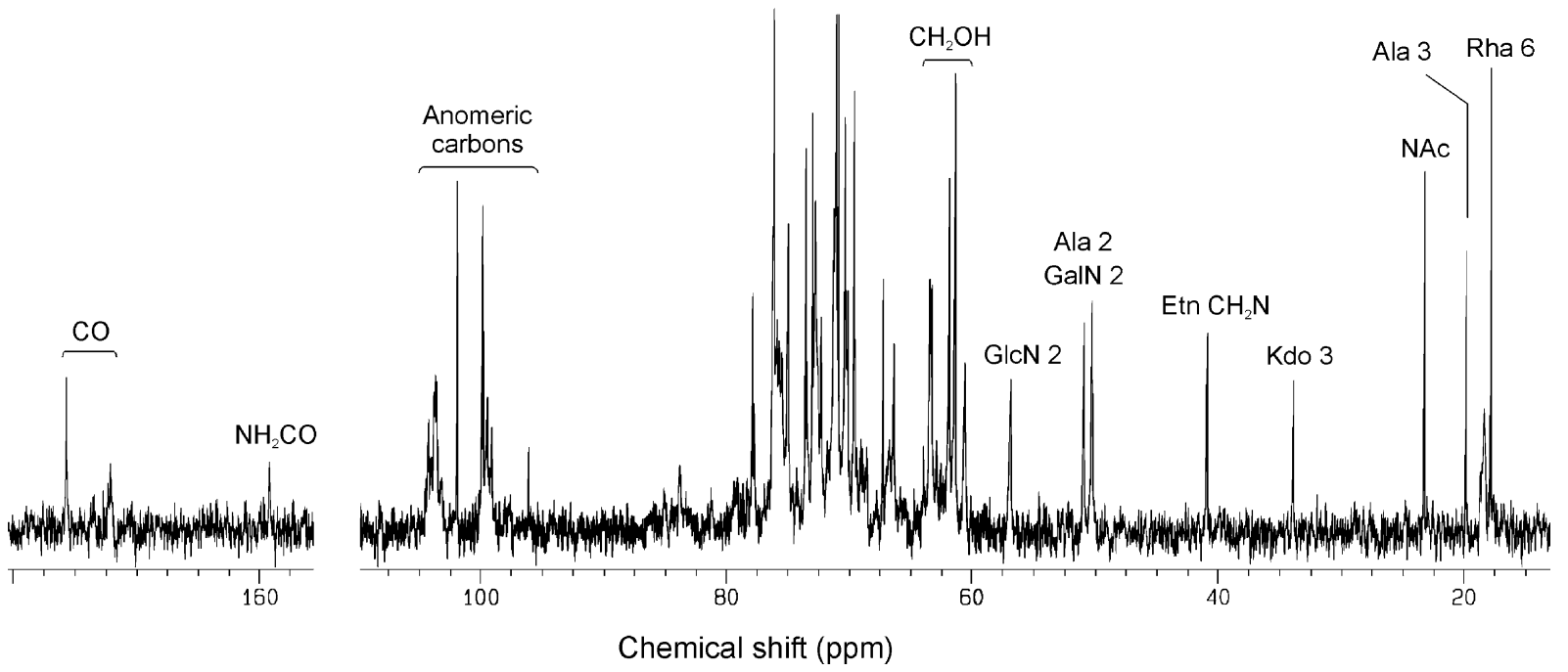

Fig. 4. ${ }^{13} \mathrm{C}-\mathrm{NMR}$ spectrum of $\mathrm{OS}_{\mathrm{HOAc}}$ obtained by mild-acid hydrolysis of the LPS. For abbreviations see legend to Fig. 2. 
Glycoform 1

$$
\begin{aligned}
& \text { L-Ala-2) }\rceil \quad \text { Etn } P---P-2)\rceil\lceil(4-P \\
& \beta \text {-GlcNAc- }(1 \rightarrow 2)-\alpha-\text { Glc }^{\mathrm{I}}-(1 \rightarrow 3)-\alpha-G a l N-(1 \rightarrow 3)-\alpha-\mathrm{Hep}^{\mathrm{II}}-(1 \rightarrow 3)-\alpha-\mathrm{Hep}^{\mathrm{I}}-(1 \rightarrow 5)-\mathrm{Kdo}^{\mathrm{I}}-(2 \rightarrow \\
& \left.\left.\left.\left.\alpha-L-R h a-(1 \rightarrow 6)-\beta-\text { Glc }^{\mathrm{II}}-(1 \rightarrow 4)\right\rfloor \quad \quad \mathrm{Cm}-7\right)\right\rfloor{ }_{(6-P} \quad \alpha-\mathrm{Kdo}^{\mathrm{II}}-(2 \rightarrow 4)\right\rfloor
\end{aligned}
$$

Fig. 5. Structures of the core region of the $P$. syringae LPS. In some molecules, position 4 of Hep $^{\mathrm{I}}$ or position 6 of Hep ${ }^{\mathrm{II}}$ is occupied by a diphosphate group. Dashed line indicates a nonstoichiometric substitution. For abbreviations see legend to Fig. 2.
Glycoform 2

$$
\begin{aligned}
& \text { L-Ala-2) }\rceil \quad \text { Etn } P---P-2)\rceil\lceil(4-P \\
& \beta \text {-GlcNAc- }(1 \rightarrow 2)-\alpha-\text { Glc }^{\mathrm{I}}-(1 \rightarrow 3)-\alpha-\text { GalN- }(1 \rightarrow 3)-\alpha-\text { Hep }^{\mathrm{II}}-(1 \rightarrow 3)-\alpha-\mathrm{Hep}^{\mathrm{I}}-(1 \rightarrow 5)-\mathrm{Kdo}^{\mathrm{I}}-(2 \rightarrow \\
& \left.\left.\alpha-\mathrm{Kdo}^{\mathrm{III}}-(2 \rightarrow 6)-\beta-\mathrm{Glc}^{\mathrm{II}}-(1 \rightarrow 4)^{\rfloor} \quad \mathrm{Cm}-7\right)^{\rfloor}{ }_{(6-P} \quad \alpha-\mathrm{Kdo}^{\mathrm{II}}-(2 \rightarrow 4)\right\rfloor
\end{aligned}
$$

vulgaris O25 [42]. Two isomeric outer core glycoforms differing in the postion of a terminal Rha residue occurs in the $P$. aeruginosa LPS [30], one of them being markedly similar to the Rha-containing glycoform of the $P$. syringae LPS core. This glycoform and only this glycoform serves to accept the O-polysaccharide chain in P. aeruginosa LPS [22,36-39], and its $P$. syringae counterpart can be assumed to have the same function. A presumable biological role of this phenomenon in smooth strains is a regulation of the content of LPS molecules with short and long carbohydrate chains on the cell surface by a predominant production of the appropriate core glycoform.

It should be noted that studies with LPS-specific monoclonal antibodies aiming at development of a recognition tool for $P$. syringae strains revealed two types of the LPS core in various strains of $P$. syringae $[17,18]$. The structure of one of them, which is shared by most strains tested $[17,18]$, was established in this work, whereas the other structure remains to be determined. Taking into account that monoclonal antibodies recognize usually the most peripheral LPS structures distal from lipid A, it can be supposed that the structural difference(s) between the two serological core types is located in the outer core region. Further studies are necessary to find out if the two core types in various strains are related to the two core glycoforms revealed in P. syringae pv. phaseolicola GSPB 711.

\section{Acknowledgements}

Authors thank H. Moll for help with HPLC and A. Kondakova for running ESI mass spectra. This work was supported by the Foundation for Leading Scientific Schools of the Russian Federation (project NSh.1557.2003.3), by grants from the Russian Foundation for Basic Research (02-04-48721 to Y.K.), INTAS (YSF 00-12 to E.Z.) and INTAS-UKRAINE (95-0142).

\section{References}

1. Young, J.M., Saddler, G.S., Takikawa, Y., DeBoer, S.H., Vauterin, L., Gardan, L., Gvozdyak, R.I. \& Stead, D.E. (1996) Names of plant pathogenic bacteria 1864-1995. ISPP Subcommittee on Taxonomy of Plant Pathogenic Bacteria. Rev. Plant Pathol. 75, 721-763.

2. Gardan, L., Shafik, H., Belouin, S., Broch, R., Grimont, F. \& Grimont, P.A. (1999) DNA relatedness among the pathovars of Pseudomonas syringae and description of Pseudomonas tremae sp. nov. \& Pseudomonas cannabina sp. nov. (ex Sutic and Dowson 1959). Int. J. Syst. Bacteriol. 49, 469-478.

3. Knirel, Y.A. \& Kochetkov, N.K. (1994) The structure of lipopolysaccharides of gram-negative bacteria. III. The structure of O-antigens. Biochemistry (Mosc.) 59, 1325-1383.

4. Ovod, V., Zdorovenko, E.L., Shashkov, A.S., Kocharova, N.A. \& Knirel, Y.A. (2000) Structure of the O polysaccharide and serological classification of Pseudomonas syringae pv. ribicola NCPPB 1010. Eur. J. Biochem. 267, 2372-2379.

5. Zdorovenko, E.L., Knirel, Y.A. \& Ovod, V.V. (1999) Structures of O-polysaccharide chains of Pseudomonas syringae pv. garcae LPS. Abstract. 13th International Congress Hungarian Soc. Microbiol. Budapest, 29 August-1 September 1999, Hungarian Soc. Microbiol, p. 112.

6. Zdorovenko, E.L., Ovod, V., Shashkov, A.S., Kocharova, N.A., Knirel, Y.A. \& Krohn, K. (1999) Structure of the O-polysaccharide of the lipopolysaccharide of Pseudomonas syringae pv. garcae ICMP 8047. Biochemistry (Mosc.) 64, 765773.

7. Zdorovenko, E.L., Zatonsky, G.V., Zdorovenko, G.M., Pasichnik, L.A., Shashkov, A.S. \& Knirel, Y.A. (2001) Structural heterogeneity in the lipopolysaccharides of Pseudomonas syringae with O-polysaccharide chains having different repeating units. Carbohydr. Res. 336, 329-336.

8. Zdorovenko, E.L., Zatonsky, G.V., Kocharova, N.A., Shashkov, A.S., Knirel, Y.A. \& Ovod, V. (2002) Structure of the O-polysaccharide of Pseudomonas syringae pv. delphinii NCPPB $1879^{\mathrm{T}}$ having side chains of 3-acetamido-3,6-dideoxy-D-galactose residues. Biochemistry (Mosc.) 67, 558-565.

9. Zdorovenko, E.L., Zatonsky, G.V., Kocharova, N.A., Shashkov, A.S., Knirel, Y.A. \& Ovod, V. (2003) Structures of the O-polysaccharides of two strains of Pseudomonas syringae pv. porri from genomospecies 4. Eur. J. Biochem. 270, 20-27.

10. Ovod, V., Zdorovenko, E.L., Shashkov, A.S., Kocharova, N.A. \& Knirel, Y.A. (2004) Structural diversity of the O polysaccharides of the lipopolysaccharides and serological classification of Pseudomonas syringae pv. garcae and other strains from genomospecies 4. Mikrobiologiya 73, 777-789.

11. Zdorovenko, G.M., Shashkov, A.S., Zdorovenko, E.L., Kocharova, N.A., Yakovleva, L.M., Knirel, Y.A. \& Rudolph, K. (2001) Characterization of the lipopolysaccharide and structure of the O-specific polysaccharide of the bacterium Pseudomonas syringae pv. atrofaciens IMV 948. Biochemistry (Mosc.) 66, 369-377.

12. Knirel, Y.A. \& Zdorovenko, G.M. (1997) Structures of O-polysaccharide chains of lipopolysaccharides as the basis for classification of Pseudomonas syringae and related strains. In Proceedings of the 5th Intern. Working Group on Pseudomonas Syringae Pathovars and Related Pathogens. Berlin, September 3-8, 1995 
(Rudolph, K., Burr, T.J., Mansfield, J.W., Stead, D., Vivian, A. \& von Kietzell, J., eds), pp. 475-480. Kluwer Academic Publishers, Dordrecht, Boston, London.

13. Zdorovenko, G.M., Gubanova, N.Y., Solyanik, L.P., Knirel, Y.A., Yakovleva, L.M. \& Zakarova, I.Y. (1991) Composition and structure of lipopolysaccharides from the strains of different pathovars of Pseudomonas syringae. Proceedings of the 4th International Working Group on Pseudomonas Syringae Pathovars, ISPP Committee on Phytopathogenic Bacteria and Università di Firenze. Florence, 1991, pp. 391-401.

14. Zdorovenko, G.M., Solyanic, L.P., Yakovleva, L.M. \& Paramonov, N.A. (1997) Characterization of O-antigens from different strains of Pseudomonas syringae pv. tabaci. Biochem. (Mosc.) 62, 28-37.

15. Zdorovenko, G.M., Varbanets, L.D., Zdorovenko, E.L., Vinarskaya, N.V. \& Yakovleva, L.M. (2004) Chemical-biological characterization of the lipopolysaccharides from collection culture of Pseudomonas syrnigae pv. maculicola IMV 381 and its dissociants. Mikrobiologiya 73, 1-12.

16. Gross, M., Mayer, H., Widemann, C. \& Rudolph, K. (1988) Comparative analysis of the lipopolysaccharides of a rough and a smooth strain of Pseudomonas syringae pv. phaseolicola. Arch. Microbiol. 149, 372-376.

17. Ovod, V., Rudolph, K. \& Krohn, K. (1997) Serological classification of Pseudomonas syringae pathovars based on monoclonal antibodies towards the lipopolysaccharide O-chains. In Proceedings of the 5th Intern. Working Group on Pseudomonas Syringae Pathovars and Related Pathogens. Berlin, September 3-8, 1995 (Rudolph, K., Burr, T.J., Mansfield, J.W., Stead, D., Vivian, A. \& von Kietzell, J., eds), pp. 526-531. Kluwer Academic Publishers, Dordrecht, Boston, London.

18. Ovod, V., Rudolph, K., Knirel, Y.A. \& Krohn, K. (1996) Immunochemical characterization of $\mathrm{O}$ polysaccharides composing the $\alpha$-D-rhamnose backbone of lipopolysaccharide of Pseudomonas syringae and classification of bacteria into serogroups $\mathrm{O} 1$ and $\mathrm{O} 2$ with monoclonal antibodies. J. Bacteriol. 178, 6459-6465.

19. Galanos, C., Lüderitz, O. \& Westphal, O. (1969) A new method for the extraction of R lipopolysaccharides. Eur. J. Biochem. 9 , 245-249.

20. Ciucanu, I. \& Kerek, F. (1984) A simple and rapid method for the permethylation of carbohydrates. Carbohydr. Res. 131, 209217.

21. Holst, O. (2000) Deacylation of lipopolysaccharides and isolation of oligosaccharide phosphates. In Bacterial Toxins. Methods and Protocols (Holst, O., ed.), pp. 345-353. Humana Press, Totowa, New Jersey.

22. Bystrova, O.V., Shashkov, A.S., Kocharova, N.A., Knirel, Y.A., Lindner, B., Zähringer, U. \& Pier, G.B. (2002) Structural studies on the core and the O-polysaccharide repeating unit of Pseudomonas aeruginosa immunotype 1 lipopolysaccharide. Eur. J. Biochem. 269, 2194-2203.

23. Bystrova, O.V., Shashkov, A.S., Kocharova, N.A., Knirel, Y.A., Zähringer, U. \& Pier, G.B. (2003) Elucidation of the structure of the lipopolysaccharide core and the linkage between the core and the O-antigen in Pseudomonas aeruginosa immunotype 5 using strong alkaline degradation of the lipopolysaccharide. Biochemistry (Mosc.) 68, 918-925.

24. Lipkind, G.M., Shashkov, A.S., Knirel, Y.A., Vinogradov, E.V. \& Kochetkov, N.K. (1988) A computer-assisted structural analysis of regular polysaccharides on the basis of ${ }^{13} \mathrm{C}-\mathrm{NMR}$ data. Carbohydr. Res. 175, 59-75.

25. Knirel, Y.A., Grosskurth, H., Helbig, J.H. \& Zähringer, U. (1995) Structures of decasaccharide and tridecasaccharide tetraphosphates isolated by strong alkaline degradation of $O$-deacylated lipopolysaccharide of Pseudomonas fluorescens strain ATCC 49271. Carbohydr. Res. 279, 215-226.
26. Bock, K. \& Pedersen, C. (1983) Carbon-13 nuclear magnetic resonance spectroscopy of monosaccharides. Adv. Carbohydr. Chem. Biochem. 41, 27-66.

27. Kosma, P., D’Souza, F.W. \& Brade, H. (1995) Synthesis of Kdotrisaccharide derivatives of chlamydial and enterobacterial LPS containing carboxyl-reduced or $\beta$-configurated Kdo-residues. J. Endotoxin Res. 2, 63-76.

28. Jansson, P.-E., Kenne, L. \& Widmalm, G. (1989) Computerassisted structural analysis of polysaccharides with an extended version of CASPER using ${ }^{1} \mathrm{H}$ - and ${ }^{13}$ C-N.M.R. data. Carbohydr. Res. 188, 169-191.

29. Knirel, Y.A., Helbig, J.H. \& Zähringer, U. (1996) Structure of a decasaccharide isolated by mild acid degradation and dephosphorylation of the lipopolysaccharide of Pseudomonas fluorescens strain ATCC 49271. Carbohydr. Res. 283, 129-139.

30. Knirel, Y.A., Bystrova, O.V., Shashkov, A.S., Kocharova, N.A., Senchenkova, S.N., Moll, H., Lindner, B., Zähringer, U., Hatano, K. \& Pier, G.B. (2001) Structural analysis of the lipopolysaccharide core of a rough, cystic fibrosis isolate of Pseudomonas aeruginosa. Eur. J. Biochem. 268, 4708-4719.

31. Sadovskaya, I., Brisson, J.-R., Lam, J.S., Richards, J.C. \& Altman, E. (1998) Structural elucidation of the lipopolysaccharide core regions of the wild-type strain PAO1 and O-chain-deficient mutant strains AK1401 and AK1012 from Pseudomonas aeruginosa serotype O5. Eur. J. Biochem. 255, 673-684.

32. Beckmann, F., Moll, H., Jäger, K.-E. \& Zähringer, U. (1995) 7-O-Carbamoyl-L-glycero-D-manno-heptose: a new core constituent in the lipopolysaccharide of Pseudomonas aeruginosa. Carbohydr. Res. 267, C3-C7.

33. Olsthoorn, M.M.A., Haverkamp, J. \& Thomas-Oates, J.E. (1999) Mass spectrometric analysis of Klebsiella pneumoniae ssp. pneumoniae rough strain $\mathrm{R} 20\left(\mathrm{Ol}^{-}: \mathrm{K} 20^{-}\right)$lipopolysaccharide preparations: Identification of novel core oligosaccharide components and three 3-deoxy-D-manno-oct-2-ulopyranosonic artifacts. J. Mass Spectrom. 34, 622-636.

34. Sanchez-Carballo, P.M., Rietschel, E.T., Kosma, P. \& Zähringer, U. (1999) Elucidation of the structure of an alanine-lacking core tetrasaccharide trisphosphate from the lipopolysaccharide of Pseudomonas aeruginosa mutant H4. Eur. J. Biochem. 261, 500508.

35. Kooistra, O., Bedoux, G., Brecker, L., Lindner, B., SanchezCarballo, P., Haras, D. \& Zähringer, U. (2003) Structure of a highly phosphorylated lipopolysaccharide core in the $\operatorname{alg} C$ mutants derived from Pseudomonas aeruginosa wild-type strains PAO1 (serogroup O5) and PAC1R (serogroup O3). Carbohydr. Res. 338, 2667-2677.

36. Bystrova, O.V., Lindner, B., Moll, H., Kocharova, N.A., Knirel, Y.A., Zähringer, U. \& Pier, G.B. (2003) Structure of the lipopolysaccharide of Pseudomonas aeruginosa O-12 with a randomly $O$-acetylated core region. Carbohydr. Res. 338, 18951905.

37. Bystrova, O.V., Lindner, B., Moll, H., Kocharova, N.A., Knirel, Y.A., Zähringer, U. \& Pier, G.B. (2003) Structure of the biological repeating unit of the O-antigen of Pseudomonas aeruginosa immunotype 4 containing both 2-acetamido-2,6-dideoxy-D-glucose and 2-acetamido-2,6-dideoxy-D-galactose. Carbohydr. Res. 338, 1801-1806.

38. Bystrova, O.V., Lindner, B., Moll, H., Kocharova, N.A., Shashkov, A.S., Knirel, Y.A., Zähringer, U. \& Pier, G.B. (2004) Full structure of the lipopolysaccharide of Pseudomonas aeruginosa immunotype 5. Biochemistry (Mosc.) 69, 170-175.

39. Sadovskaya, I., Brisson, J.-R., Thibault, P., Richards, J.C., Lam, J.S. \& Altman, E. (2000) Structural characterization of the outer core and the O-chain linkage region of lipopolysaccharide from Pseudomonas aeruginosa serotype O5. Eur. J. Biochem. 267, 16401650. 
40. Leone, S., Izzo, V., Silipo, A., Sturiale, L., Garozzo, D., Lanzetta, R., Parrilli, M., Molinaro, A. \& Di Donato, A. (2004) A novel type of highly negatively charged lipooligosaccharide from Pseudomonas stutzeri OX1 possessing two 4,6-O-(1-carboxy)ethylidene residues in the outer core region. Eur. J. Biochem. 271, 2691-2704.

41. Silipo, A., Leone, S., Molinaro, A., Lanzetta, R. \& Parrilli, M. (2004) The structure of the phosphorylated carbohydrate back- bone of the lipopolysaccharide of the phytopathogen bacterium Pseudomonas tolaasii. Carbohydr. Res. 339, 2241-2248.

42. Vinogradov, E., Cedzynski, M., Rozalski, A., Ziolkowski, A. \& Swierzko, A. (2000) The structure of the carbohydrate backbone of the core-lipid A region of the lipopolysaccharide from Proteus vulgaris serotype O25. Carbohydr. Res. 328, 533-538. 